\title{
Placental Diffusing Capacities at Varied Carbon Monoxide Tensions
}

\author{
John M. Bissonnette, Walter K. Wickham, and Willa H. Drummond \\ From the Department of Obstetrics and Gynecology, School of Medicine, University of Oregon \\ Health Sciences Center, Portland, Oregon 97201
}

\begin{abstract}
A B S TRACT To test the hypothesis that carbon monoxide transfer across the placenta is, in part, a facilitated process, we have looked for evidence of saturation kinetics for carbon monoxide. In eight pregnant ewes, fetal to maternal carbon monoxide transfer was examined in a preparation in which the fetal side of the placenta was perfused with blood. The carboxyhemoglobin concentrations on the fetal side of the placenta were varied from 4.8 to $70 \%$ in 23 measurements. At increased carbon monoxide tensions, the transfer from fetus to mother always decreased. The slope of log rate of carbon monoxide transfer vs. log partial pressure gradient across the placenta was significantly different from 1. Placental membrane diffusing capacity was calculated separately from total placental diffusing capacity which includes hemoglobin reaction rates and erythrocyte membrane diffusion. Placental membrane diffusing capacity decreased at increased carbon monoxide tensions. Placental permeability for urea did not change with increasing carbon monoxide tensions. These results are consistent with the hypothesis that carbon monoxide diffusion in the placenta is, in part, carrier mediated.
\end{abstract}

\section{INTRODUCTION}

In a series of recent communications (1-5), Gurtner and Burns have proposed that oxygen transfer in the placenta is, in part, carrier mediated. These authors have suggested that the carrier might be cytochrome $\mathrm{P}-450$ as proposed by Longmuir et al. (6). The studies

Presented in part at the 26th Annual Fall Meeting of the American Physiological Society, 5-10 October 1975, San Francisco, Calif.

Dr. Bissonnette is the recipient of Research Career Development Award K04 HD-00139 from the U. S. Public Health Service.

Received for publication 1 July 1975 and in revised form 3 February 1977. were carried out in pregnant ewes using a preparation in which the umbilical circulation is perfused while the maternal uterine circulation remains intact. These authors have shown that: $(a)$ apparent oxygen diffusing capacity is 15-70 times greater than argon diffusing capacity $(4) ;(b)$ changing the solubility of argon or nitrogen in either the perfusate or the maternal circulation does not result in any change in placental diffusing capacity, while an increase in oxygen solubility does result in an increase in oxygen diffusion (5); and (c) that compounds which bind to cytochrome P-450 decrease the placental transfer of oxygen but not of argon (1-3).

Oxygen transfer from mother to fetus is influenced by uterine and umbilical blood flows, placental oxygen consumption, and the distribution of maternal and fetal blood flows within the exchange units of the placenta, as well as the permeability characteristics of the tissues which separate the maternal and fetal erythrocytes (7). Carbon monoxide (CO) placental permeability is dependent only on diffusion across the placental tissues and, diffusion across the erythrocyte membranes plus the reaction rates with hemoglobin (8). Because there would be less variables involved, we chose carbon monoxide to study the question of facilitated transport in the placenta. We reasoned that if there is a carrier for carbon monoxide then if the transport system is offered a large enough quantity of $\mathrm{CO}$ it would tend to become saturated. If the $\mathrm{CO}$ carrier were saturated transplacental flux would then take place only by simple diffusion and we should observe a fall in the rate of transfer at high CO tensions. To isolate the placental membrane diffusion from the total CO transport system (placental membrane, erythrocyte membrane, and hemoglobin reaction) we have calculated membrane diffusing capacity separately.

Since Longo (8) had found a linear relationship 
between placental CO transfer $\left(\dot{V}_{C O}\right)^{1}$ and CO partial pressure gradient between uterine vein and umbilical vein up to $18 \%$ carboxyhemoglobin ([HbCO ]) we decided our studies would have to include higher CO saturation. We have used the umbilical circulation perfusion preparation for two reasons. First, it enabled us to saturate blood on one side of the placenta with up to $70 \%$ [HbCO] which would be impossible in an intact preparation. Second, by measuring the transfer of $\mathrm{CO}$ from the fetal to the maternal circulation, we were insured of a large sink for the CO which crossed the placenta so that even at higher $\mathrm{CO}$ tensions there would be negligible back pressure.

\section{METHODS}

The studies were performed using ewes between 125 days gestation and term (147-150 days). Spinal anesthesia (tetracaine, $30-40 \mathrm{mg}$ ) was employed. Both umbilical arteries and both umbilical veins were cannulated. The umbilical circulation was perfused with adult sheep blood at $39^{\circ} \mathrm{C}$. The perfusion rate was always $50 \mathrm{ml} / \mathrm{min}$. The volume of the oxygenator in the perfusion system was $500 \mathrm{ml}$. The gas tensions with which the oxygenator blood was equilibrated were $\mathrm{O}_{2}, 3.8 \%$ and $\mathrm{CO}_{2}, 6.7 \%$. $25 \mathrm{mg}$ of phenoxybenzamine was injected into the umbilical artery tubing at the start of perfusion. CO was added to the oxygenator by equilibrating various quantities of blood with $100 \% \mathrm{CO}$ in syringes. Oxygenator $\mathrm{CO}$ tension was reduced by exchanging with large volumes of blood which had no added CO. The perfusion of the umbilical circulation was not interrupted after the flow had started. After a new level of CO had been established we waited 20-30 min before measuring the placental diffusing capacity $\left(\mathrm{D}_{\mathrm{P}_{\mathrm{co}}}\right)$. Blood samples were simultaneously drawn from the umbilical artery, umbilical vein, and the maternal uterine vein, and analyzed for $\mathrm{CO}$ content, $\mathrm{Po}_{2}, \mathrm{pH}$, and hemoglobin. The characteristics of each preparation are listed in Table I. Umbilical artery pressures were constant to within $5 \mathrm{~mm} \mathrm{Hg}$ throughout the experiments.

$\mathrm{PO}_{2}$ and $\mathrm{pH}$ were determined at $39^{\circ} \mathrm{C}$ on a blood gas analyzer (Radiometer Co., Copenhagen). CO content was measured by the standard ferricyanide method (9) using an infrared analyzer (Beckman Instruments, Inc., Fullerton, Calif.). By varying the amount of blood analyzed (1 or $2 \mathrm{ml}$ ) and the output of the infrared analyzer, sensitivities of 0.006 , $0.013,0.025$, and $0.038 \mathrm{ml} \mathrm{CO} / 100 \mathrm{ml}$ blood were obtained. The most sensitive setting was used at low [HbCO] and the 0.038 setting for highest [HbCO]. In this way the sensitivity averaged $9.7 \pm 3.6 \%$ (SD) of the gradient between fetal artery and vein. In five repeated measurements from the same sample the SD was $1.2 \%$ of the mean. A second extraction with oxygen in samples with $50 \%$ [HBCO] was made and no residual CO detected. Hemoglobin was determined by the cyanmethemoglobin method (10). Hemo-

${ }^{1}$ Abbreviations used in this paper: [HbCO], carboxyhemoglobin saturation; $\left[\mathrm{HbO}_{2}\right]$, oxyhemoglobin saturation; $\mathrm{PO}_{2}$, partial pressure of oxygen; PCO, partial pressure of carbon monoxide; $\triangle \mathrm{PCO}$, partial pressure gradient across the placenta for $\mathrm{CO} ; \mathrm{D}_{\mathbf{P}_{\mathrm{co}}}$, total placental diffusing capacity for carbon monoxide; $D_{\text {Mco }}$ membrane diffusing capacity; VCO, rate of transfer of carbon monoxide from fetus to mother; $P_{\text {urea, }}$ placental permeability of urea; $P_{50}$, the partial pressure of oxygen at which blood is $50 \%$ saturated with oxygen.
TABLE I

Characteristics of Experimental Preparations

\begin{tabular}{|c|c|c|c|c|c|c|}
\hline $\begin{array}{l}\text { Animal } \\
\text { number }\end{array}$ & $\begin{array}{c}\text { Fetal } \\
\text { weight }\end{array}$ & $\begin{array}{c}\text { Placental } \\
\text { weight }\end{array}$ & $\begin{array}{c}\text { Maternal } \\
\text { hemoglobin } \\
\text { type }\end{array}$ & $\begin{array}{c}\text { Perfusion } \\
\text { blood } \\
\text { hemoglobin } \\
\text { type }\end{array}$ & $\begin{array}{c}\text { Perfusion } \\
\text { pressure }\end{array}$ & $\begin{array}{c}\text { Duration } \\
\text { of } \\
\text { perfusion }\end{array}$ \\
\hline & g & $g$ & & & $m m ~ H g$ & $h$ \\
\hline 1 & 2,800 & 252 & B & B & 30 & 1.8 \\
\hline 2 & 2,000 & 342 & B & B & 35 & 2.1 \\
\hline 3 & 1,136 & 99 & B & B & 50 & 1.8 \\
\hline 4 & 2,500 & 255 & B & B & 30 & 1.7 \\
\hline \multirow[t]{2}{*}{5} & 2,281 & 275 & & & & \\
\hline & 3,347 & 329 & $\mathrm{AB}$ & B & 30 & 1.2 \\
\hline \multirow[t]{2}{*}{6} & 3,100 & 355 & & & & \\
\hline & 3,400 & 358 & $\mathrm{AB}$ & $\mathbf{A B}$ & 35 & 1.9 \\
\hline \multirow[t]{2}{*}{7} & 2,400 & 177 & & & & \\
\hline & 3,125 & 170 & B & $\mathrm{AB}$ & 35 & 1.9 \\
\hline 8 & 3,421 & 185 & $\mathrm{AB}$ & AB & 37 & 1.9 \\
\hline Mean & 2,683 & 254 & & & 35.3 & 1.8 \\
\hline SD & \pm 708 & \pm 88 & & & \pm 6.6 & \pm 0.3 \\
\hline SEM & \pm 214 & \pm 26 & & & \pm 2.3 & \pm 0.1 \\
\hline
\end{tabular}

The characteristics of the animal preparation and placental blood perfusion data used in this study. In animals 5-7 only one of twin umbilical circulations was perfused.

globin types were determined by starch gel electrophoresis (11).

Fetal to maternal urea permeability studies were carried out as follows: $50 \mu \mathrm{Ci}$ of $\left[{ }^{14} \mathrm{C}\right]$ urea (sp act $5-8 \mathrm{mCi} / \mathrm{mmol}$; New England Nuclear, Boston, Mass.) was premixed in $6.0 \mathrm{ml}$ blood and then added in three divided quantities to the oxygenator 15-20 min before each measurement of $D_{P c o}$. Blood samples for isotope determination were obtained from the three vessels at the same time as measurements for $\mathrm{D}_{\mathrm{Pco} .}$. Blood samples were prepared as follows: to $0.5 \mathrm{ml}$ blood, $2.0 \mathrm{ml}$ water and $0.5 \mathrm{ml} 30 \%$ trichloroacetic acid were added. After centrifugation at $5,000 \mathrm{rpm}$ for $10 \mathrm{~min}, 0.5 \mathrm{ml}$ of the supernate was added to $10 \mathrm{ml}$ of scintillation fluid (Aquasol, New England Nuclear) and counted for $10 \mathrm{~min}$.

Calculations. Fetal to maternal CO transfer was calculated from:

$$
\dot{\mathrm{V}} \mathrm{CO}=\dot{\mathrm{Q}} \times\left([\mathrm{CO}]_{\mathrm{fa}}-[\mathrm{CO}]_{\mathrm{rv}}\right) / 100,
$$

where, $\dot{\mathrm{V}} \mathrm{CO}=\mathrm{CO}$ transferred, $\mathrm{ml} / \mathrm{min}$, standard temperature and pressure, dry; $Q=$ umbilical blood flow, $\mathrm{ml} / \mathrm{min}$; $[\mathrm{CO}]_{\mathrm{ra}}$ and $[\mathrm{CO}]_{\mathrm{fv}}=\mathrm{CO}$ content $(\mathrm{ml} / 100 \mathrm{ml}$ blood $)$ in the fetal artery and fetal vein. Placental diffusing capacity for CO was calculated from:

$$
\mathrm{D}_{\mathrm{P}_{\mathrm{co}}}=\dot{\mathrm{V}} \mathrm{CO} /\left(\mathrm{PCO}_{\mathrm{fv}}-\mathrm{PCO}_{\mathrm{mv}}\right) \text {, }
$$

where, $D_{\mathrm{P}_{\mathrm{CO}}}=$ placental diffusing capacity, $\mathrm{ml} / \mathrm{min}$ per $\mathrm{mm}$ $\mathrm{Hg}$, standard temperature and pressure dry; $\mathrm{PCO}_{\mathrm{fv}}$ and $\mathrm{PCO}_{\mathrm{mv}}$ $=$ partial pressure of $\mathrm{CO}$ in umbilical vein and maternal uterine vein.

The partial pressure gradient for $\mathrm{CO}$ across the placenta was calculated using the measurement in fetal umbilical vein and maternal uterine vein and is not the mean gradient across the exchanging capillaries. This approach has been previously used (8). The partial pressure of $\mathrm{CO}$ was determined from the Haldane expression (12), using the value of 218 for M (8). Oxygen saturations were determined mathe- 
TABLE II

Placental-Diffusing Capacities during Fetal to Maternal Exchange

\begin{tabular}{|c|c|c|c|c|c|c|c|c|c|c|c|c|c|}
\hline \multirow{2}{*}{$\begin{array}{c}\text { Ani- } \\
\text { mal } \\
\text { num- } \\
\text { ber }\end{array}$} & \multirow{2}{*}{$\begin{array}{c}\text { Exper- } \\
\text { iment } \\
\text { num- } \\
\text { ber }\end{array}$} & \multicolumn{3}{|c|}{ Umbilical artery } & \multicolumn{3}{|c|}{ Umbilical vein } & \multicolumn{3}{|c|}{ Uterine vein } & \multirow[b]{2}{*}{$\dot{\mathrm{V}} \mathrm{co}$} & \multirow[b]{2}{*}{$\mathrm{DP}_{\text {co }}$} & \multirow[b]{2}{*}{$\mathrm{DP}_{\mathrm{co}} / \mathrm{kg}$} \\
\hline & & $\begin{array}{c}\mathrm{CO} \\
\text { content }\end{array}$ & [HbCO] & Pco & $\begin{array}{c}\text { CO } \\
\text { content }\end{array}$ & [HbCO] & Pco & $\begin{array}{c}\mathrm{CO} \\
\text { content }\end{array}$ & {$[\mathrm{HbCO}]$} & PCO & & & \\
\hline & & $\mathrm{ml} / 100 \mathrm{ml}$ & $\%$ & $m m \mathrm{Hg}$ & $\mathrm{ml} / 100 \mathrm{ml}$ & $\%$ & $\mathrm{~mm} \mathrm{Hg}$ & $\mathrm{ml} / 100 \mathrm{ml}$ & $\%$ & $m m \mathrm{Hg}$ & $\mathrm{ml} / \mathrm{min}$ & $\begin{array}{l}\mathrm{ml} / \mathrm{min} / \\
\mathrm{mm} \mathrm{Hg}\end{array}$ & $\begin{array}{c}\mathrm{ml} / \mathrm{min} / \\
\mathrm{mm} \mathrm{Hg} \\
\times \mathrm{kg}\end{array}$ \\
\hline \multirow[t]{3}{*}{1} & 1 & 1.039 & 7.39 & 0.033 & 0.939 & 6.8 & 0.025 & 0.099 & 0.73 & 0.003 & 0.050 & 2.27 & 0.81 \\
\hline & 2 & 2.027 & 15.0 & 0.065 & 1.868 & 14.1 & 0.050 & 0.146 & 1.08 & 0.004 & 0.080 & 1.74 & 0.62 \\
\hline & 3 & 3.061 & 22.6 & 0.091 & 2.862 & 22.7 & 0.086 & 0.196 & 1.45 & 0.005 & 0.099 & 1.22 & 0.44 \\
\hline \multirow[t]{3}{*}{2} & 4 & 0.818 & 6.1 & 0.022 & 0.729 & 5.55 & 0.019 & 0.145 & 0.73 & 0.003 & 0.044 & 2.75 & 1.38 \\
\hline & 5 & 3.641 & 27.5 & 0.090 & 3.435 & 27.0 & 0.091 & 0.136 & 0.68 & 0.003 & 0.103 & 1.17 & 0.59 \\
\hline & 6 & 5.440 & 46.7 & 0.181 & 5.243 & 43.0 & 0.155 & 0.575 & 2.89 & 0.012 & 0.098 & 0.69 & 0.35 \\
\hline \multirow[t]{3}{*}{3} & 7 & 0.769 & 4.83 & 0.018 & 0.714 & 4.55 & 0.016 & 0.239 & 1.36 & 0.005 & 0.028 & 2.55 & 2.25 \\
\hline & 8 & 2.024 & 12.6 & 0.045 & 1.901 & 11.9 & 0.040 & 0.237 & 1.35 & 0.005 & 0.061 & 1.74 & 1.53 \\
\hline & 9 & 3.288 & 20.5 & 0.072 & 3.156 & 19.6 & 0.065 & 0.259 & 1.48 & 0.006 & 0.066 & 1.12 & 0.99 \\
\hline \multirow[t]{3}{*}{4} & 10 & 0.707 & 4.89 & 0.022 & 0.663 & 4.67 & 0.017 & 0.121 & 0.92 & 0.004 & 0.022 & 1.69 & 0.68 \\
\hline & 11 & 0.909 & 6.72 & 0.030 & 0.852 & 6.29 & 0.024 & 0.115 & 0.89 & 0.003 & 0.029 & 1.38 & 0.55 \\
\hline & 12 & 1.277 & 9.08 & 0.039 & 1.220 & 8.67 & 0.034 & 0.105 & 0.80 & 0.003 & 0.029 & 0.94 & 0.38 \\
\hline \multirow[t]{3}{*}{5} & 13 & 8.514 & 64.2 & 0.237 & 7.845 & 61.6 & 0.264 & 0.397 & 2.51 & 0.008 & 0.335 & 1.31 & 0.39 \\
\hline & 14 & 7.828 & 64.2 & 0.237 & 7.282 & 61.8 & 0.267 & 0.434 & 2.53 & 0.008 & 0.273 & 1.05 & 0.31 \\
\hline & 15 & 6.326 & 51.9 & 0.204 & 5.671 & 49.8 & 0.193 & 0.470 & 2.56 & 0.008 & 0.327 & 1.77 & 0.53 \\
\hline \multirow[t]{2}{*}{6} & 16 & 4.833 & 28.2 & 0.077 & 4.534 & 26.0 & 0.076 & 0.218 & 1.24 & 0.004 & 0.149 & 2.07 & 0.61 \\
\hline & 17 & 2.079 & 11.4 & 0.034 & 1.911 & 10.5 & 0.031 & 0.167 & 0.93 & 0.003 & 0.084 & 2.99 & 0.88 \\
\hline \multirow[t]{3}{*}{7} & 18 & 13.096 & 70.8 & 0.380 & 12.647 & 67.9 & 0.336 & 0.316 & 1.92 & 0.007 & 0.225 & 0.68 & 0.22 \\
\hline & 19 & 11.480 & 60.8 & 0.244 & 11.251 & 59.6 & 0.237 & 0.293 & 1.78 & 0.007 & 0.115 & 0.50 & 0.16 \\
\hline & 20 & 2.016 & 10.7 & 0.040 & 1.848 & 9.92 & 0.043 & 0.184 & 1.09 & 0.004 & 0.084 & 2.15 & 0.69 \\
\hline \multirow[t]{3}{*}{8} & 21 & 4.451 & 45.8 & 0.145 & 4.114 & 44.2 & 0.145 & 0.194 & 1.45 & 0.005 & 0.169 & 1.13 & 0.33 \\
\hline & 22 & 3.251 & 34.5 & 0.118 & 2.994 & 33.4 & 0.095 & 0.198 & 1.48 & 0.005 & 0.129 & 1.43 & 0.46 \\
\hline & 23 & 0.853 & 7.78 & 0.032 & 0.728 & 6.55 & 0.026 & 0.131 & 0.93 & 0.003 & 0.063 & 2.74 & 0.88 \\
\hline
\end{tabular}

The measurements in each animal preparation are listed in the order in which they were performed. [HbCO] $=$ carboxyhemoglobin saturation; PCO = partial pressure of carbon monoxide; $\dot{V}$ CO $=$ carbon monoxide transferred from fetus to mother: $\mathrm{DP}_{\mathrm{co}}=$ placental carbon monoxide diffusing capacity. $\mathrm{DP}_{\mathbf{c o}} / \mathrm{kg}=$ placental carbon monoxide diffusing capacity per $\mathrm{kilogram}$ fetal weight.

matically from the $\mathrm{PO}_{2}$ and $\mathrm{pH}$. A Bohr factor of 0.49 (13) arid 2.6 (14) as the slope of the log-log relationship between $\mathrm{O}_{2}$ saturation and $\mathrm{PO}_{2}$ were used. $\mathrm{A}_{50}$ of 41 for type $\mathrm{B}$ and 36 for type $\mathrm{AB}$ sheep bloods, were determined by a method previously described (15). The $P_{50}$ was adjusted for the effect of $\mathrm{CO}$ by the method of Roughton and Darling (16). In two instances at [HbCO] of 7 and $50 \%, \mathrm{O}_{2}$ content was independently measured ( $\mathrm{Lex}-\mathrm{O}_{2}-\mathrm{Con}$, Lexington Instruments Corp., Waltham, Mass.). The oxygen saturations obtained from these values were within $1 \%$ of the mathematically determined values. An example of the calculation of PCO can be seen using the values in the fetal artery of animal 1 experiment 1 (Table II). PCO $=[\mathrm{HbCO}] \times \mathrm{Po}_{2} / \mathrm{M}$ $\times\left[\mathrm{HbO}_{2}\right]$. The $\mathrm{CO}$ content was $1.039 \mathrm{ml} / 100 \mathrm{ml}$ and the hemoglobin $10.5 \mathrm{~g} / 100 \mathrm{ml}$. The [HbCO] is therefore $7.39 \%$. The $\mathrm{PO}_{2}$ was $23.9 \mathrm{~mm} \mathrm{Hg}$. Type $\mathrm{B}$ blood was used in the perfusate and has a $\mathrm{P}_{50}$ of $41 \mathrm{~mm} \mathrm{Hg}$; at [HbCO] $7.5 \%$ this falls to $35.5 \mathrm{~mm} \mathrm{Hg}$. At a $\mathrm{Po}_{2}$ of $23.9 \mathrm{~mm} \mathrm{Hg}$ the calculated $\left[\mathrm{HbO}_{2}\right]$ was $24.4 \%$. PCO then is $7.39 \times 23.9$ / $218 \times 24.4=0.033 \mathrm{~mm} \mathrm{Hg}$.

Because $D_{P_{c o}}$ as calculated above includes the reaction rates of $\mathrm{CO}$ with hemoglobin, the erythrocyte membrane diffusion, as well as the placental membrane diffusion, we have calculated the latter separately. This was done by rearranging the equation of Longo et al. (17) from:

$$
1 / D_{\mathrm{P}_{\mathrm{Co}}}=1 / \theta_{\mathrm{m}_{\mathrm{Co}}} \mathrm{Vc}_{\mathrm{m}}+1 / \mathrm{D}_{\mathrm{M}_{\mathrm{co}}}+1 / \theta_{\mathrm{f}_{\mathrm{Co}}} \mathrm{Vc}_{\mathrm{f}} \text {, }
$$

to

$$
1 / \mathrm{D}_{\mathrm{M}_{\mathrm{Co}}}=1 / \mathrm{D}_{\mathrm{P}_{\mathrm{CO}}}-1 / \theta_{\mathrm{f}_{\mathrm{CO}}} \mathrm{Vc}_{\mathrm{f}}-1 / \theta_{\mathrm{m}_{\mathrm{Co}}} \mathrm{Vc}_{\mathrm{m}},
$$

where, $\mathrm{D}_{\mathrm{M}_{\mathrm{co}}}=$ membrane diffusion capacity, $\mathrm{ml} / \mathrm{min}$ per $\mathrm{mm}$ $\mathrm{Hg} ; \boldsymbol{\theta}_{\mathrm{m}_{\mathrm{CO}}}, \boldsymbol{\theta}_{\mathrm{f}_{\mathrm{co}}}=$ rate of $\mathrm{CO}$ exchange between erythrocytes and plasma on the maternal and fetal sides, $\mathrm{ml} / \mathrm{min}$ per $\mathrm{mm} \mathrm{Hg}$ $\times \mathrm{ml} ; \mathrm{Vc}_{\mathrm{m}} . \mathrm{Vc}_{\mathrm{f}}=$ capillary volumes on the maternal and fetal sides of the placenta, ml.

The value for $\theta_{\text {co }}$ in adult sheep blood used was 0.76 $\mathrm{ml} / \mathrm{min}$ per $\mathrm{mm} \mathrm{Hg} \times \mathrm{ml}$ (18). $\theta_{\text {co }}$ may change depending on the levels of $\left[\mathrm{HbO}_{2}\right],[\mathrm{HbCO}]$, and reduced hemoglobin present. At the levels present in these experiments, no measurements of $\theta_{\mathrm{co}}$ have been made. However, Forster (19) has presented arguments which show that $\theta_{\text {co }}$ remains constant over the range $15-90 \%$ reduced hemoglobin. Only when reduced hemoglobin falls below $15 \%$ does $\theta_{\text {co }}$ begin to rapidly decline (see Fig. 3 in reference 19). Thus we have reduced $\theta_{\mathrm{co}}$ only when the combined $\left[\mathrm{HbO}_{2}\right]$ and [HbCO] saturations exceed $85 \%$. We have assumed that capillary volume on the maternal and fetal sides of the 
placenta were equal. We used the value $13.7 \mathrm{ml} / \mathrm{kg}$ fetal weight for capillary volume, a value determined in previous studies using single-injection double-indicator dilution technique $(20)$ at the perfusion pressures $(35 \mathrm{~mm} \mathrm{Hg}$ ) used in the present studies. Mean capillary $\left[\mathrm{HbO}_{2}\right]$ was calculated from mean capillary $\mathbf{P O}_{2}$. The latter was estimated from arterial $\mathrm{Po}_{2} \times 0.33+$ venous $\mathrm{PO}_{2} \times 0.66$. An example of the calculation of $\mathrm{D}_{\mathrm{M}_{\mathrm{co}}}$ is taken from animal 7 experiment 18 of Table II. $1 / \mathrm{D}_{\mathrm{M}_{\mathrm{co}}}=1 / 0.218-1 / 0.64 \times 13.7-1 / 0.76 \times 13.7$. Mean capillary $\left[\mathrm{HbO}_{2}\right]+[\mathrm{HbCO}]$ on the fetal side of the placenta was $92 \%$ and therefore, $\theta_{\mathrm{t}_{\mathrm{co}}}$ was reduced to 0.64 . $\mathrm{D}_{\mathrm{M}_{\mathrm{co}}}=0.228 \mathrm{ml} / \mathrm{min}$ per $\mathrm{mm} \mathrm{Hg} \times \mathrm{kg}$. Placental permeability for $\left[{ }^{14} \mathrm{C}\right]$ urea was calculated from:

$$
\mathbf{P}=\dot{\mathbf{Q}}\left(\mathrm{cpm}_{\mathrm{fa}}-\mathrm{cpm}_{\mathrm{fv}}\right) /\left(\mathrm{cpm}_{\mathrm{fv}}-\mathrm{cpm}_{\mathrm{mv}}\right),
$$

where, $\mathbf{P}=$ permeability, $\mathrm{ml} / \mathrm{min} ; \dot{\mathbf{Q}}=$ umbilical blood flow $\mathrm{ml} / \mathrm{min} ; \mathrm{cpm}=$ counts per minute per milliliter in umbilical artery (fa); umbilical vein (fv) and maternal uterine vein (mv).

\section{RESULTS}

23 placental diffusing capacities for $\mathrm{CO}$ were measured in eight preparations. The $\mathrm{CO}$ content, [HbCO], $\mathrm{P}_{\mathrm{co}}, \dot{\mathrm{V}}_{\mathrm{co}}$, and $\mathrm{D}_{\mathrm{P}_{\mathrm{co}}}$ values obtained are presented in Table II. The values listed in Table II are in the order in which measurements were made in each preparation. The $\mathrm{PO}_{2}$ in the umbilical artery was $25.4 \pm 5.0$ (mean $\pm \mathrm{SD}$ ), in the umbilical vein 29.7 \pm 8.7 , in the maternal uterine vein $52.9 \pm 8.9$, and in the uterine artery $77 \pm 6.5$. It can be seen that placental CO diffusing capacity is always decreased with increased $\mathrm{CO}$ tensions on the fetal side of the placenta.

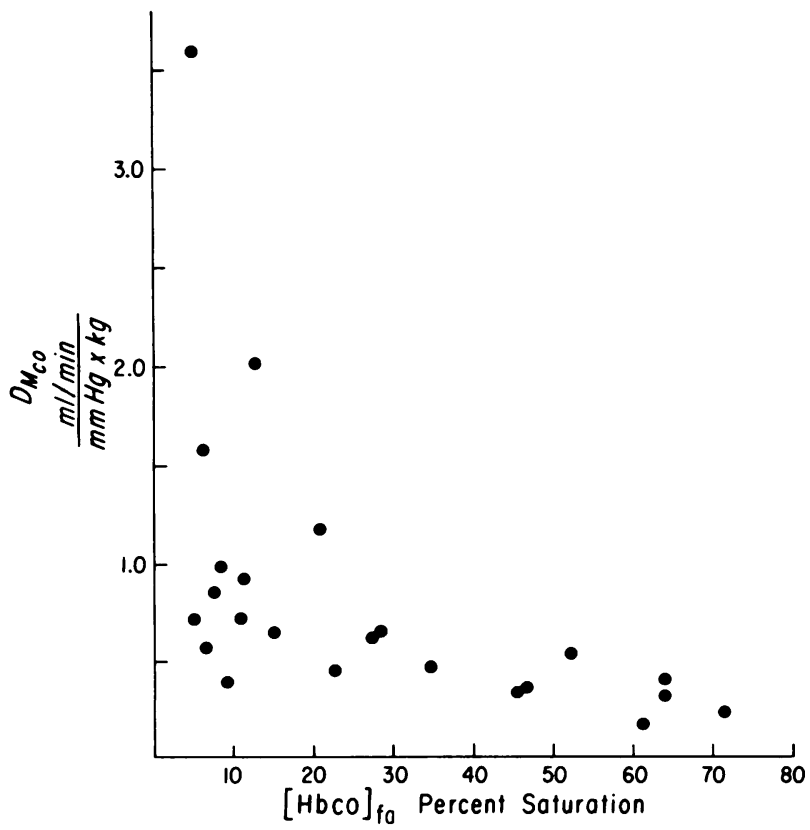

FIGURE 1 Membrane diffusing capacity $\left(\mathrm{D}_{\mathrm{M}_{\mathrm{co}}}\right)$ as a function of carboxyhemoglobin concentration in the fetal artery $\left([\mathrm{HbCO}]_{\mathrm{fa}}\right)$.
TABLE III

Placental Urea Permeability at Varied Carboxyhemoglobin Saturations

\begin{tabular}{cccc}
\hline $\begin{array}{c}\text { Animal } \\
\text { number }\end{array}$ & {$\left[\mathrm{HbCO}_{\text {ta }}\right.$} & $\mathrm{P}_{\text {urea }}$ & Decrease \\
\hline \multirow{3}{*}{4} & $\%$ & $m l / m i n$ & $\%$ \\
& 6.72 & 40.1 & \\
5 & 9.08 & 33.9 & 15.5 \\
& 64.2 & 36.5 & \\
& 64.2 & 36.7 & \\
6 & 51.9 & 32.8 & 10.1 \\
& 28.2 & 37.7 & \\
7 & 11.4 & 38.9 & -3.2 \\
& 70.8 & 38.8 & \\
& 60.8 & 33.2 & \\
8 & 10.7 & 38.4 & 1.0 \\
& 45.8 & 34.3 & \\
& 34.5 & 32.1 & 18.4 \\
\hline
\end{tabular}

The measurements were made simultaneously with carbon monoxide transfer (Table II) and are listed in the order in which they were performed. $[\mathrm{HbCO}]_{\mathrm{fa}}=$ carboxyhemoglobin saturation in the fetal umbilical artery, $P_{\text {urea }}=$ placental permeability for urea.

This was observed whether the measurements went from low to high CO tensions (preparations 1-3) or from high to low CO tensions (preparations 6-8).

If a linear relationship exists between fetal to maternal transfer of $\mathrm{CO}$ and the partial pressure gradient across the placenta $\left(\Delta \mathrm{P}_{\mathrm{co}}\right)$ then a log-log plot of these two variables will have a slope of unity. The slope of $\log \mathrm{VCO} / \mathrm{kg}$ fetal weight vs. $\log \Delta \mathrm{PCO}$ for all measurements in Table II is 0.55 with $95 \%$ confidence limits of $0.71-0.38(r=0.90)$. Therefore, the relationship between $\mathrm{CO}$ transport across the placenta and partial pressure gradient is not linear.

In Fig. 1 the membrane diffusing capacity $\left(D_{M_{c o}}\right.$ $\mathrm{ml} / \mathrm{min}$ per $\mathrm{mm} \mathrm{Hg} \times \mathrm{kg}$ ) is plotted against [HbCO] in the fetal artery. In only three instances did the value of reduced hemoglobin fall below $15 \%$ resulting in a decrease in $\theta_{\text {co }}$ for fetal capillary blood. It can be seen that when the placenta is perfused with blood at high $[\mathrm{HbCO}]$ the membrane diffusing capacity is reduced.

In five preparations (4-8) placental transfer of $\left[{ }^{14} \mathrm{C}\right]$ urea was measured at the same time as the $\mathrm{CO}$ diffusing capacities were determined. These results are presented in Table III. As in Table II, the results are listed in the order in which the measurements were made in each preparation. Urea permeability was stable in two preparations (6 and 7) and fell $10.1-18.4 \%$ in the other three. However, 
this change in urea transfer was possibly related to duration of the experiment but not to the carboxyhemoglobin level on the fetal side of the placenta.

\section{DISCUSSION}

CO placental diffusing capacity has been previously measured in sheep (8). The authors mixed CO in the ewe's respiratory gases in a closed circuit. The uptake of CO was measured in the intact fetal circulation over a 50-min period. In eight experiments they obtained a value of $0.54 \pm 0.15 \mathrm{ml} / \mathrm{min}$ per $\mathrm{mm} \mathrm{Hg} \times \mathrm{kg}$ for

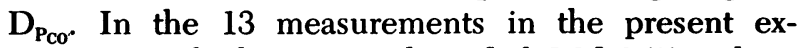
periments which were made at [HbCO] $25 \%$ or less, the value for $D_{P_{c o}}$ is $0.93 \pm 0.52$. Although our measurement is higher, the values are not significantly different ( $P>0.05 ; t$ test for unpaired samples).

Increasing the $\mathrm{CO}$ tension at which $\mathrm{CO}$ transfer is measured always resulted in a fall in the rate of CO transport (Table II). Grouping the data from all eight preparations has shown that the relationship between $\mathrm{CO}$ transferred from fetus to mother and the partial pressure gradient across the placenta is not linear. The movement of $\mathrm{CO}$ from fetal blood across the placenta to the maternal compartment involves the dissociation from fetal hemoglobin, fetal erythrocyte diffusion, membrane diffusion in the placenta, and combination with maternal blood. We have therefore made separate calculations which show that membrane diffusing capacity falls at increased CO tensions (Fig. 1). It has been shown that $\theta_{\text {co }}$ for the dissociation step in human blood is equal to $\theta_{\mathrm{CO}}$ for the combination reaction (21).

The question of a change in $\theta_{\text {fco }}$ at high [HbCO] saturations is critical to our conclusions. If $\theta_{\text {co }}$ falls on the fetal side of the placenta then the decrease in $D_{P_{c o}}$ observed may be due to a reduction in erythrocyte unloading of $\mathrm{CO}$ and not to any change in placental membrane transport processes. As outlined in the methods section we have followed the arguments of Forster (19), and in our calculation of $D_{\mathbf{M}_{\mathrm{co}}}$ for Fig. $1, \theta_{\text {ico }}$ was only reduced when reduced hemoglobin was less than $15 \%$.

As an alternate approach let us examine the necessary change in $\theta_{\mathrm{fco}}$ which would explain the present findings. $D_{\mathrm{P}_{\text {co }}}$ at $[\mathrm{HbCO}]$ up to $25 \%$ is $0.93 \pm 0.52$ $(n=13)$ whereas at $25-75 \%$ [HbCO], it falls to 0.39 $\pm 0.15(n=10)(P<0.01)$. The reciprocal of diffusing capacity $\left(1 / \mathrm{D}_{\mathrm{P}_{\mathrm{co}}}\right)$ is the resistance to diffusion from fetal to maternal blood. Longo et al. (17) have concluded that the resistance of the erythrocytes in the fetal placental capillaries is $20 \%$ of the total resistance. In the present studies we find that resistance goes from 1.08 to 2.54 at $\mathrm{HbCO}$ over $25 \%$. If all of this 2.4-fold increase in resistance were taking place in the erythrocytes on the fetal side of the placenta; then, in the absence of a change in fetal capillary volumes, $\theta_{\text {fco }}$ would have to fall by a factor of 7.8 . The $20 \%$ resistance for fetal erythrocyte (17) is based on a fetal capillary blood volume of $3.3 \mathrm{ml} / \mathrm{kg}$. We have shown that this value is probably too small $(20)$ and at the higher value $(13.7 \mathrm{ml} / \mathrm{kg})$ the resistance in fetal erythrocytes falls to $10 \%$. While $\theta_{\text {fco }}$ may be changing in our studies it is unlikely that this factor can explain the magnitude of decline in $D_{\mathrm{P}_{\mathrm{co}}}$ which was observed at [HbCO] saturation over $25 \%$.

It has been shown that a modest (11-14\%) reduction in pulmonary diffusing capacity for $\mathrm{CO}$ can be caused by an uneven distribution of pulmonary blood flow to diffusing capacity (22). However, in order for capillary blood CO tensions to rise to significant levels, in those segments with long transit times, measurements were made with alveolar $P_{c o}$ of about $25 \mathrm{~mm}$ $\mathrm{Hg}$ (22). This greatly exceeds our maximum $\mathrm{P}_{c 0}$ in fetal arterial blood $(0.380 \mathrm{~mm} \mathrm{Hg})$. Nevertheless, we have followed the approach of Hyde and coauthors (22) to evaluate what effect uneven distribution of maternal to fetal flow rates in the placenta could have on our interpretation of the data. The uptake of CO by the maternal blood at any interval of time will be

$$
\mathrm{d}[\mathrm{CO}]_{\mathrm{m}} / \mathrm{dt}=\mathrm{D}_{\mathrm{Pco}_{\mathrm{C}}}\left(\mathrm{PCO}_{\mathrm{f}}-\mathrm{PCO}_{\mathrm{m}}\right) / \mathrm{Vc}_{\mathrm{m}},
$$

where $\mathrm{d}[\mathrm{CO}]_{\mathrm{m}} / \mathrm{dt}$ is the milliliters of CO taken up by the maternal blood per unit time; $\mathrm{D}_{\mathrm{P}_{\mathrm{co}}}$ is the placental diffusing capacity for $\mathrm{CO}(\mathrm{ml} / \mathrm{min}) ; \mathrm{PCO}_{\mathrm{f}}$ and $\mathrm{PCO}_{\mathrm{m}}$ are the $\mathrm{CO}$ partial pressures in the fetal and maternal capillaries as they enter the exchange unit and $\mathrm{Vcm}$ is the maternal capillary blood volume.

We have chosen our experimental value with the highest $\mathrm{PCO}_{\mathrm{f}}(0.380 \mathrm{~mm} \mathrm{Hg}$ from animal 7, experiment 18) at entry on the fetal side. Assuming that the observed fall in $\mathrm{D}_{\mathrm{P}_{c o}}$ at $70.8 \%$ [HbCO] may be due to build up of $\mathrm{CO}$ tension in maternal blood in areas with a low flow rate, we allowed $\mathrm{D}_{\mathrm{P}_{\mathrm{co}}}$ to equal 2.15 $\mathrm{ml} / \mathrm{min}$ the value obtained at $[\mathrm{HbCO}]$ of $10.7 \%$ in this animal. We used a value of $0.004 \mathrm{~mm} \mathrm{Hg}$ for $\mathrm{PCO}_{\mathrm{m}}$ at entry to the exchange with fetal blood and 42.8 $\mathrm{ml}$ as maternal capillary blood volume. We calculated the uptake of $\mathrm{CO}$ by the maternal blood at 0.1-s intervals and from the capacities of fetal and maternal bloods obtained the new values for [ $\mathrm{HbCO}]$ and PCO in both fetal and maternal blood. We repeated the calculations until fetal [HbCO] had fallen to the measured umbilical vein value of $67.9 \%$. This took $18.3 \mathrm{~s}$ which corresponds to a maternal flow rate of $140 \mathrm{ml} / \mathrm{min}$. At this time maternal end capillary blood had a [HbCO] of $4.40 \%$ with a Pco of $0.0167 \mathrm{~mm} \mathrm{Hg}$. This can be contrasted with the measured maternal uterine vein values of $1.92 \%$ and $0.007 \mathrm{~mm} \mathrm{Hg}$. Thus, it can be seen that even if there are areas 
of maternal blood flow with long transit times the driving pressure from the fetal blood in our blood to blood exchange of $\mathrm{CO}$ is insufficient to allow a significant back pressure on the maternal side.

The influence of physiological shunts (23-25) should not be an important factor in placental $\mathrm{CO}$ exchange. Even at the very low flow rate in the fetal umbilical circulation used in these experiments the ratio of $\mathrm{CO}$ partial pressure in the fetal vein to that in the fetal artery was $0.90 \pm 0.12$, so that unlike oxygen the contribution of any change in shunt fractions would not significantly alter the results. Although we are not aware of any direct measurements which address the question, we have assumed that $\mathrm{CO}$ is not consumed by the placenta.

In simple diffusion across the placenta, the determinants for gas transfer primarily involve the diffusional distances between maternal and fetal bloods and the area of exchange. In the sheep placenta, area is primarily dependent on the maternal and fetal capillary volumes. We have recently shown that fetal capillary volume is altered by perfusion pressure (20). In the present series of experiments the perfusion pressure remained stable with a tendency to increase $(5 \mathrm{~mm} \mathrm{Hg})$ with duration of the experiment. Over the range of pressures observed $(25-35 \mathrm{~mm} \mathrm{Hg})$ both distension and recruitment of previously unperfused fetal placental capillaries may have taken place (20). This would result in an increase in diffusing capacity. Alternatively, if the increase in perfusion pressure at constant flow represents edema this would result in a decrease in diffusion. We have attempted to deal with this effect by measuring $\mathbf{D}_{\mathbf{P}_{\text {co }}}$ while going from low to high $\mathrm{CO}$ tensions in some preparations and from high to low tensions in others. In both instances we find a decrease in $D_{P_{c o}}$ with high CO tension.

It may be argued that in the range of [HbCO] 30$70 \%$ the placental tissues become hypoxic and the fall in diffusion is a nonspecific effect. However, our measurements of urea transfer were not affected by increasing [ $\mathrm{HbCO}]$ on the fetal side of the placenta (Table III). Urea permeability in the sheep placenta is membrane limited (26). While the pathways of transfer for urea may not be the same as those for CO (hydrophilic vs. lipid routes), these measurements argue against a severe disruption of placental membrane transport.

In summary, we have considered a number of alternate explanations for the fall in $\mathrm{CO}$ transfer at elevated CO tensions. None of these seem to provide a satisfactory alternate interpretation of our data. The measurements obtained in these experiments are consistent with the hypothesis of a $\mathrm{CO}$ carrier in the placental membrane.

\section{ACKNOWLEDGMENTS}

The authors thank Dr. R. D. Koler, in whose laboratory the starch-gel electrophoreses were performed. The helpful suggestions of Dr. G. G. Power concerning analysis of the data is greatly appreciated.

The study was supported by grant HL-17150 from the U.S. Public Health Service.

\section{REFERENCES}

1. Gurtner, G. H., and B. Burns. 1972 Possible facilitated transfer of oxygen across the placenta. Nature (Lond.). 240: 473-475.

2. Gurtner, G. H., and B. Burns. 1973. The role of cytochrome P-450 of placenta in facilitated oxygen diffusion. Drug Metab. Dispos. 1: 368-373.

3. Burns, B., and G. H. Gurtner. 1973. A specific carrier for oxygen and carbon monoxide in the lung and placenta. Drug Metab. Dispos. 1: 374-379.

4. Gurtner, G., and B. Burns. 1973. Further evidence for a specific $\mathrm{O}_{2}$ carrier in the placenta. Physiologist. 16: 331. (Abstr.)

5. Gurtner, G., and B. Burns. 1975. Physiological evidence consistent with the presence of a specific $\mathrm{O}_{2}$ carrier in the placenta. J. Appl. Physiol. 39: 728-734.

6. Longmuir, I. S., S. Sun, and W. Soucie. 1973. Possible role of cytochrome $\mathrm{P}-450$ as a tissue oxygen carrier. In Oxidases and Related Redox Systems. T. E. King, H. S. Mason, and M. Morrison, editors. University Park Press, Baltimore. 2: 451-461.

7. Longo, L. D., and G. G. Power. 1969. Analysis of $\mathbf{P O}_{2}$ and $\mathrm{PCO}_{2}$ differences between maternal and fetal blood in the placenta. J. Appl. Physiol. 26: 48-55.

8. Longo, L. D., G. G. Power, and R. E. Forster, II. 1967. Respiratory function of the placenta as determined with carbon monoxide in sheep and dogs. J. Clin. Invest. 46: 812-828.

9. Coburn, R. F., G. K. Danielson, W. S. Blakemore, and R. E. Forster, II. 1964. Carbon monoxide in blood; analytical method and sources of error. J. Appl. Physiol. 19: 510-515.

10. Drabkin, D. L., and J. H. Austin. 1935. Spectrophotometric studies. V. A technique for the analysis of undiluted blood and concentrated hemoglobin solutions. J. Biol. Chem. 112: 105-115.

11. Smithies, O. 1959. An improved procedure for starchgel electrophoresis: further variation in the serum proteins of normal individuals. Biochem. J. 71: 585-587.

12. Haldane, J., and J. L. Smith. 1897. The absorption of oxygen by the lungs. J. Physiol. (Lond.). 22: 231-258.

13. Huisman, T. H. J., and J. Kitchens. 1968. Oxygen equilibria studies of the hemoglobins from normal and anemic sheep and goats. Am. J. Physiol. 215: 140-146.

14. Naughton, M. A., G. Meschia, F. C. Battaglia, A. Hellegers, H. Hagopian, and D. H. Barron. 1963. Hemoglobin characteristics and the oxygen affinity of the bloods of dorset sheep. Q. J. Exp. Physiol. Cogn. Med. Sci. 48: 313-323.

15. Edwards, M. J., and R. J. Martin. 1966. Mixing technique for the oxygen-hemoglobin equilibrium and Bohr effect. J. Appl. Physiol. 21: 1898-1902.

16. Roughton, F. J. W., and R. C. Darling. 1944. The effect of carbon monoxide on the oxyhemoglobin dissociation curve. Am. J. Physiol. 141: 17-31.

17. Longo, L. D., G. G. Power, and R. E. Forster, II. 1969. Placental diffusing capacity for carbon monoxide 
at varying partial pressures of oxygen. J. Appl. Physiol. 26: $360-370$.

18. Lawson, W. H., Jr. 1971. Effect of anemia, species, and temperature on $\mathrm{CO}$ kinetics with red blood cells. J. Appl. Physiol. 31: 447-457.

19. Forster, R. E. 1964. Rate of gas uptake by red cells. Handb. Physiol. 1 (Sect. 3. Respiration.): 827-837.

20. Bissonnette, J. M. 1975. Control of vascular volumes in the sheep umbilical circulation. J. Appl. Physiol. 38: 1057-1061.

21. Power, G. G., and W. C. Bradford. 1969. Measurement of pulmonary diffusing capacity during blood-to-gas exchange in humans. J. Appl. Physiol. 27: 61-66.

22. Hyde, R. W., M. G. Marin, R. I. Rynes, G. Karreman, and R. E. Forster. 1971. Measurement of uneven distribution of pulmonary blood flow to CO diffusing capacity. J. Appl. Physiol. 31: 605-612.

23. Metcalfe, J., W. Moll, H. Bartels, P. Hilpert, and J. T. Parer. 1965. Transfer of carbon monoxide and nitrous oxide in the artificially perfused sheep placenta. Circ. Res. 16: 95-101.

24. Faber, J. J. 1969. Application of the theory of heat exchangers to the transfer of inert materials in placentas. Circ. Res. 24: 221-234.

25. Rankin, J. H. G., and E. N. Peterson, 1969. Application of the theory of heat exchangers to a physiological study of the goat placenta. Circ. Res. 24: 235-250.

26. Boyd, R. D. H., C. Haworth, T. E. Stacey, and R. H. T. Ward. 1976. Permeability of the sheep placenta to unmetabolized polar nonelectrolytes. J. Physiol. (Lond.). 256: 617-634. 